УДК 656.224

\title{
РОЗВИТОК ШВИДКІСНОГО ПАСАЖИРСЬКОГО РУХУ В УКРАЇНІ НА ОСНОВІ ВСЕСВІТНЬОГО ДОСВІДУ
}

\author{
Канд. техн. наук О.А. Малахова, магістр О.М. Анікєєва \\ РАЗВИТИЕ СКОРОСТНОГО ПАССАЖИРСКОГО ДВИЖЕНИЯ В УКРАИНЕ НА ОСНОВЕ \\ ВСЕМИРНОГО ОПЫТА
}

\section{Канд. техн. наук Е.А. Малахова, магистр О.Н. Аникеева THE DEVELOPMENT OF HIGH-SPEED PASSENGER MOVEMENT IN UKRAINE BASED WORLD EXPERIENCE}

\section{Cand. of tehn sciences O. Malakhova, master student O. Anikeeva}

Вирішення питання підвищення швидкості руху поїздів при перевезеннях пасажирів має найважливіше значення як для залізниці, так і для клієнтів. Розвиток рейкового високошвидкісного транспорту позитивно виливає на інфраструктуру великих міст, призводить до скорочення кількості транспортних подій, шкідливого впливу на навколишнє середовище, підвищує конкурентоспроможність залізничного транспорту.

Ключові слова: транспорт, пасажиропотік, швидкісний рух, залізничні лінії, перевезення.

Решение вопроса повышения скорости движения поездов при перевозках пассажиров имеет важнейтее значение как для железной дороги, так и для клиентов. Развитие рельсового высокоскоростного транспорта положстельно влияет на инфраструктуру крупных городов, приводит к сокращению количества транспортных происшествий, вредного воздействия на окружаюшую среду, повышает конкурентоспособность железнодорожного транспорта.

Ключевые слова: транспорт, пассажиропоток, скоростное движение, железнодорожные линии, перевозки.

Solution of the question increasing speed of trains for passengers is central importance for the railway, as well as for customers. The development of high-speed rail transport infrastructure has a positive effect on major cities, leading to a reduction in the number of accidents, harmful effects on the environment, improves the competitiveness of rail transport.

Keywords: transportation, passenger, high-speed traffic, railways, transportation.

Вступ. Тенденції до збільшення мобільності населення, усвідомлення негативних наслідків невтримної автомобілізації, особливо в екологічному відношенні, необхідність економії енергетичних ресурсів нафтового походження - ці й інші фактори визначають необхідність розвитку швидкісних i високошвидкісних пасажирських перевезень рейковим транспортом. Воно сприяе розширенню зон тяжіння великих міст, зниженню транспортних подій, шкідливого впливу на навколишнє середовище, пришвидшує науково-технічний прогрес на залізничному транспорті, у транспортному будівництві й транспортному машинобудуванні, підвищує конкурентоспроможність залізничного транспорту [1].
Швидкісний рух пасажирських поїздів дає змогу скоротити витрати часу пасажира на поїздку й тим самим підвищити якість транспортних послуг. Завдяки цій та іншим перевагам у порівнянні 3 іншими видами транспорту швидкісні й високошвидкісні напрямки руху стають економічно й екологічно чистою складовою частиною світової транспортної системи [2].

Прискорення дальніх пасажирських перевезень було й залишається однією 3 основних проблем розвитку залізниць у всіх індустріально розвинених країнах світу й насамперед у країнах Західної Європи і Японії, що викликано рядом причин:

- прагненням забезпечити масові перевезення пасажирів у регіонах 3 високою 
щільністю населення й вирішити проблему освоєння швидко зростаючих перевезень на малі й середні відстані, ліквідувавши незадоволеність попиту;

- бажанням створити умови для зведення до мінімуму тривалості поїздок, що при досить високому рівні комфорту залучає пасажирів на залізничний транспорт і поліпшує його економічні показники;

- необхідністю збільшення перевізної здатності існуючих залізничних ліній;

- економією енергетичних ресурсів, у першу чергу нафтопродуктів, шляхом переключення пасажирських потоків 3 авіаційного й автомобільного транспорту на залізничний;

- усвідомленням негативних наслідків невтримної автомобілізації, особливо в екологічному відношенні.

Постановка проблеми. В умовах різкого падіння обсягу можливих інвестицій підвищується актуальність удосконалення всього процесу управління інвестиційною діяльністю, у тому числі всебічний технікоекономічний аналіз вибору варіантів будівництва таких високошвидкісних магістралей або реконструкції існуючих ліній для збільшення швидкостей руху поїздів. Високошвидкісні магістралі в нинішній ситуації гострої нестачі коштів у нас будуть побудовані не скоро. Будуть потрібні величезні капітальні вкладення, які не окупляться в найближчі десятиліття. Тому тільки реконструктивні заходи створять можливість високошвидкісного руху до 200-250 км/год на діючих лініях. Але вивчення всесвітнього досвіду допоможе уникнути помилок у виборі маршрутів курсування швидкісних поїздів та скоротити непродуктивні експлуатаційні витрати.

Мета i задачі дослідження. Процес вирішення поставленої проблеми включає розгляд таких завдань:

- аналіз поточного стану у сфері швидкісного та високошвидкісного руху пасажирських поїздів на закордонних залізницях та в Україні;

$$
\text { - аналіз пасажиропотоку та }
$$

пасажирообороту, зокрема на основних напрямках при виділенні ключових сполучень та пілотних маршрутів;
- постановка та вирішення задачі раціоналізації маршрутів руху швидкісних пасажирських поїздів.

Виклад основного матеріалу. У розвитку високошвидкісної мережі зацікавлені як залізничні компанії країн Європи, так i Європейський Союз (ЄС), ухвалені рішення якого визначили напрямки розвитку транс'європейської залізничної мережі. Початок європейської високошвидкісної залізничної мережі було покладено в 1981 р. будівництвом високошвидкісної лінії Париж Ліон (TGV Sud-Est) довжиною 470 км, розрахованої спочатку на максимальну швидкість руху 260 км/год, що у 2001 р. була підвищена до 300 км/год. Міжнародних масштабів високошвидкісна залізнична мережа набула 3 моменту появи проекту PBKAL (скорочено за першими буквами ПарижБрюссель-Келн-Амстердам-Лондон) [2].

Наприкінці 1980-х рр. ряд європейських залізничних адміністрацій на чолі 3 Національним товариством залізниць Франції й Німеччини підготували перші пропозиції щодо розвитку європейської високошвидкісної залізничної мережі, які в грудні 1990 р. після дороблення були надані європейській комісії. Пропозиція європейської комісії в 1990 р. по високошвидкісних пасажирських залізничних магістралях стала відправною точкою для процесу планування розвитку високошвидкісної залізничної мережі в Свропі.

Ці ініціативи основані на таких офіційних документах [3]:

- директива 91/440/СЕС, яка визначає параметри розвитку залізниць країн - членів $\mathrm{CC}$ із подальшим розвитком концепції в директиві 2001/12/EEC;

- рішення 1692/96/ЄС Європейського парламенту й Ради по розвитку транс'європейської залізничної транспортної мережі;

- директива 96/48/€С з експлуатаційної сумісності на транс'європейській мережі високошвидкісних залізничних магістралей;

- директива 2001/16/€С 3 експлуатаційної сумісності на транс'європейській мережі звичайних залізничних ліній.

За цими директивами було розпочато розроблення й прийняття технічних вимог 3 техніко-експлуатаційної сумісності (TSI) i нових європейських стандартів (EN). При цьому високошвидкісні системи виступили в ролі піонера в галузі стандартизації [2]. 


\section{Експлуатація залізниць}

Залізниці почали самостійні спроби 3 організації й розвитку високошвидкісного пасажирського руху з перетинанням кордонів держав Європи до появи ініціативи на високому рівні. Першим стало порівняльне дослідження високошвидкісних залізничних систем у межах франко-німецької угоди 1978 р. У галузі рухомого складу в дослідженні розглядалися тоді ті високошвидкісні пасажирські поїзди TGV (Франція), ICE (Німеччина) i Transrapid 07 (Німеччина), що перебували ще в стадії розроблення. В інфраструктурній частині дослідження розглядалася гіпотетична тоді ще залізнична лінія Франкфурт-Париж, що проектувалася тільки на папері й використовувалася лише для порівняння інженерних параметрів французької й німецької систем розвитку високошвидкісних залізничних магістралей.
За підсумками зустрічі міністрів транспорту Франції й Німеччини в Ла-Рошелі 22 травня 1992 р. був запропонований новий варіант траси високошвидкісної залізничної лінії 3 Парижа через східну Францію на південний захід Німеччини. Основними частинами нового варіанта були нова високошвидкісна лінія LGV Est European між Парижем i Страсбургом, реконструйоване продовження лінії POS North у напрямку Саарбрюкен-Мангейм і далі до Франкфурта-наМайні, продовження POS South у напрямку Кельн-Штутгарт, на яких планували експлуатувати пасажирські поїзди серій TGV POS (Франція) і ICE-3M (Німеччина), тобто поїзди нових поколінь із підвищеними швидкостями руху [4]. Динаміка пасажирообороту за період з 1965 по 2012 pp. наведена на рис. 1.

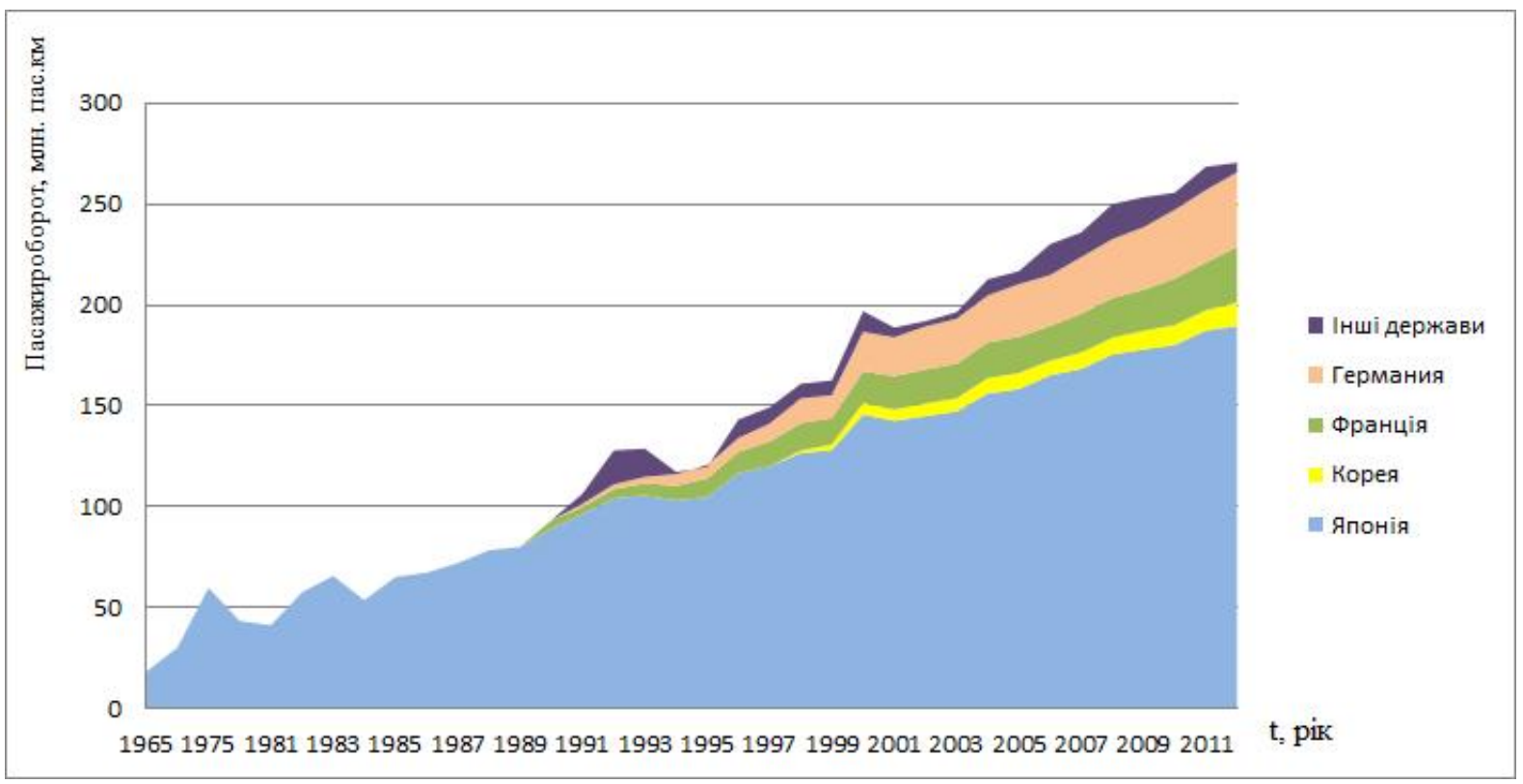

Рис. 1. Динаміка пасажирообороту за період з 1965 по 2012 рр.

У січні 2008 р. стали можливими високошвидкісні пасажирські сполучення на всіх ділянках високошвидкісної магістралі Кельн-Париж-Брюссель-Кельн/Амстердам 3 уведенням в експлуатацію нової високошвидкісної лінії HSL Zuid між Амстердамом i Антверпеном. Залізнична мережа високошвидкісних пасажирських сполучень у Центральній Свропі наведена на рис. 2. Завдяки високошвидкісним пасажирським поїздам тривалість поїздки в межах європейської мережі істотно скоротилася. 


\section{Експлуатація залізниць}

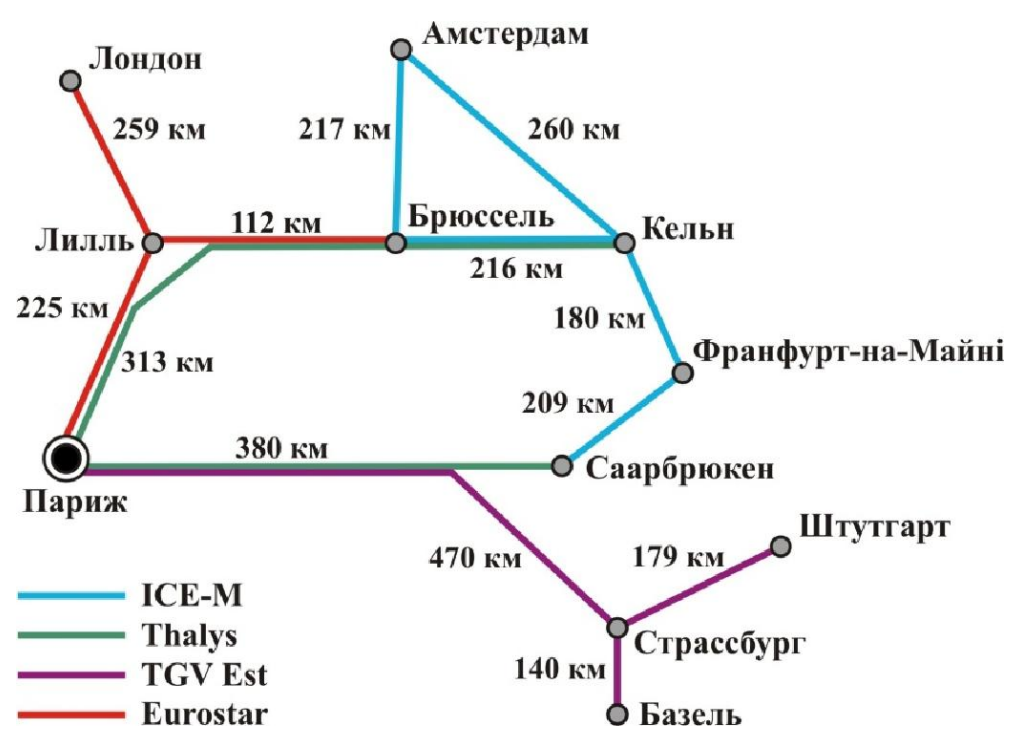

Рис. 2. Мережа високошвидкісного сполучення в Центральній Європі

За останні 15 років за замовленням МСЖД франко-німецький консорціум у складі незалежних інститутів прогнозів провів два масштабних дослідження відносно ймовірних обсягів пасажирських перевезень високошвидкісними пасажирськими поїздами 3 урахуванням відтоку перевезень пасажирів 3 автомобільного й авіаційного транспорту. Результати цих досліджень показують, що пасажирооборот високошвидкісним залізничним рухомим складом складе 226 млрд пас.км до 2020 p.

Останнім часом набули розповсюдження, у тому числі і в Україні, поїзди категорії Інтерсіті та ІнтерСіті+ [5]. InterCity (ІнтерСіті) - це клас швидкісних міжміських поїздів у ряді європейських країн, відмітною особливістю яких $\epsilon$ те, що вони роблять проміжні зупинки на шляху прямування тільки у великих містах країни або на вузлових станціях. Саме це відрізняє поїзди класу ІнтерСіті від приміських і пасажирських поїздів [6].

В Україні поїзди ІнтерСіті й ІнтерСіті+ з'явилися завдяки підготовці країни до чемпіонату Євро-2012 незважаючи на те, що Укрзалізниця планувала впровадження швидкісних поїздів такого класу ще на початку минулого десятиліття. Так, однією зі спроб став поїзд «Столичний Експрес», що поєднав Київ 3 Харковом і з Дніпропетровськом, а пізніше і зі Львовом. Час у дорозі становив 5-7 год, що на той момент було значною економією часу для пасажирів. Укрзалізниця прийняла рішення ввести швидкісні міжміські поїзди і для інших напрямків, однак до 2006 р. цей напрямок розвивався дуже повільно. У 2007 р., коли стало відомо, що Україна прийме матчі Євро2012, розвиток швидкісного руху поїздів було включено в стратегічний план підготовки до чемпіонату.

При розвитку швидкісного руху на залізницях України необхідним $\epsilon$ технікоекономічне обгрунтуванні проектів швидкісних магістралей. Слід виходити 3 того, що ефект, отриманий в інших галузях i сферах суспільства від організації швидкісного руху, багаторазово перевершує галузеву вигоду самого транспорту.

3 огляду на специфіку основних технологічних процесів на транспорті $\epsilon$ перспективним використання математичного апарату теорії графів. Характерними прикладами може служити i робота 3 визначення оптимальних маршрутів руху швидкісних поїздів на залізницях України. Разом $з$ тим багатокритеріальність зазначених завдань управління, а також їх програмноматематичне забезпечення не повною мірою враховує специфіку деяких завдань, підвищує ймовірність помилкових дій 3 боку людиниоператора i, як наслідок, імовірність збоїв у роботі пасажирських станцій, зривів графіків руху поїздів i неправильного використання пропускної спроможності залізниць. У зв'язку з цим формалізація (математичний опис) завдань управління транспортними системами на основі 


\section{Експлуатація залізниць}

використання задачі комівояжера [4] актуальна, оскільки дає змогу використовувати розроблені автоматизовані методи прийняття обгрунтованих рішень.

Висновок. Проблема підвищення швидкості руху пасажирських поїздів на залізницях України повинна стати одним 3 найважливіших аспектів соціальної політики держави, а транспортні проекти та програми у сфері пасажирських перевезень повинні сприйматися не як комерційні підприємства, а як проекти макроекономічного рівня. На сьогоднішній день головною метою $\epsilon$ створення умов для підвищення мобільності населення, розвитку міжрегіональних економічних i культурних зв'язків на основі реалізації програми розвитку високошвидкісного і швидкісного сполучення в Україні в першу чергу між найбільшими центрами країни, що дає змогу скоротити час на шляху прямування.

\section{Список використаних джерел}

1. Аветикян, А.Л. Высокоскоростное движение: достижения, проблемы, перспективы [Текст] / А.Л. Аветикян // Железнодорожный транспорт. - 1968. - № 9. - С. 74-79.

2. Анисимов, П.С. Высокоскоростные железнодорожные магистрали и пассажирские поезда [Текст]: монография / П.С. Анисимов, А.А. Иванов. - М.: ФГОУ "Учебно-методический центр по образованию на железнодорожном транспорте", 2011. - 542 с.

3. Лакот, Ф. Французский опыт создания высокоскоростных магистралей [Текст] / Ф. Лакот // Инженер путей сообщения. - 1998. - № 2. - С. 24-25.

4. Элин, В.В. Скоростные железнодорожные линии в Западной Европе [Электронный ресурс]. - Режим доступа: http://commi.narod.ru/txt/1990/0317.htm. - Загл. с экрана.

5. Понятие «Инетрсити». Начало курсированияю [Электронный ресурс]. - Режим доступа: http://intercity.kiev.ua/o-poezdah-intercity. - Загл. с экрана.

6. Макаров, І.П. Моделі проектування мережі маршрутів міського пасажирського транспорту. Моделювання управління транспортними системами [Текст] / І.П. Макаров, В.В. Ямпільський. Владивосток: ДВНЦ АН СССР, 1977. - 439 с.

7. Задача о коммивояжере [Электронный ресурс]. - Режим доступа: http://gendocs.ru/v35168. Загл. с экрана.

Рецензент д-р техн. наук, професор О.М. Огар

Малахова Олена Анатоліївна, канд. техн. наук, доцент кафедри управління експлуатаційною роботою Українського державного університету залізничного транспорту. Тел. (057)730-10-89; e-mail: alena_mal@mail.ru.

Анікєєва Оксана Миколаївна, магістр ІППК. Тел. (067) 530-87-55; e-mail: julyjul64@gmail.com.

Malakhova Olena Anatoliivna, PhD. Of tehn. Sciences, Associate Professor of Management of operational work of the Ukrainian State University of Railway Transport. Tel. (057)730-10-89; e-mail: alena_mal@mail.ru. Anikeeva Oksana Mikolaevna, Listener IPPK. Tel.(067) 530-87-55 e-mail: julyjul64@gmail.com.

Наукова праця здана до друку 30.06.2015 року 